\title{
ПСИХОЛОГІЧНІ ЧИННИКИ ВПЛИВУ НА ПРОФЕСІЙНЕ СТАНОВЛЕННЯ МАЙБУТНІХ МЕДИЧНИХ СЕСТЕР
}

\author{
Л. В. Задирака \\ Ватутінська філія Черкаського медичного коледжу \\ ДВНЗ «Тернопільський державний медичний університет \\ імені І. Я. Горбачевського МОЗ Украӥни»
}

У статті наведено емпіричні результати вивчення психологічних чинників впливу на професійне становлення майбутніх медичних сестер. Встановлено зв'язок навчальної мотивації з окремими комунікативними установками у досліджуваних.

\section{PSYCHOLOGICAL FACTORS OF IMPACT ON THE PROFESSIONAL COMPETENCE OF FUTURE NURSES}

\author{
L. V. Zadyraka \\ The filial of Cherkasy Medical College in Vatutine, \\ I. Horbachevsky Ternopil State Medical University
}

This article presents the results of empirical results of psychosocial factors of impact on the professional development of future nurses. The relationship of educational motivation with individual communicative units of the investigated was established.

Вступ. За останні роки в Україні відбуваються реформаційні процеси в освітній галузі, спрямовані на досягнення рівня світових стандартів. У зв'язку з цим, основною вимогою до вищих навчальних закладів України $є$ реалізація нових підходів та методів, які забезпечать якісну професійну підготовку майбутніх фахівців.

Сучасний рівень розвитку медичної науки й охорони здоров'я поряд з іншими аспектами визначається також і зміною вимог Галузевого стандарту вищої освіти до кваліфікаційної характеристики медичної сестри [11].

Розробка засобів реалізації формування професійної компетентності, дослідження проблем його впровадження в практику вищої школи, технологізація цього процесу перебуває в центрі наукових педагогічних досліджень. Залежно від поєднання цих обставин і знаходиться динаміка формування професійної компетентності студента - майбутнього професіонала [2]. Випускник професійного освітнього закладу повинен бути готовий самостійно й ефективно вирішувати проблеми в галузі професійної діяльності, позитивно взаємодіяти і співпрацювати з колегами, прагнути до постійного професійного зростання та творчої самореалізації, володіти стійким прагненням до самовдосконалення та самореалізації.

(с) Л. В. Задирака, 2016
На сучасному етапі дослідження встановлено, що досі зусилля вчених були спрямовані на вдосконалення рівня підготовки майбутніх медсестер (М. В. Блохіна, Н. А. Сербіновська, Л. І. Вассерман, А. В. Дружинін, В. Є. Коган), розв'язання питання збереження здоров'я самих медичних працівників (І. М. Кайдалова, В. В. Косарєв), професійного становлення медичних працівників середньої ланки (Л. Б. Виноградов, В. В. Ярцев та ін.) [3].

У працяхтакихучених, як К. А. Аяпов, І..Бубликова, 3. В. Гапонова, Г. М. Перфільєва, Ф. Е. Вартанян, О. А. Орлов, Н. І. Гаврилов, В. П. Фофанов, С. А. Мухіна, І. І. Тарновська та інші, підкреслюється важливість проблеми формування професійної компетентності медичних сестер та пропонується звернути увагу на систему підготовки спеціалістів сестринської справи з урахуванням перспектив розвитку потреб охорони здоров'я.

Основна частина. Виділяють такі функціональні й структурні компоненти професійної самосвідомості медичної сестри: когнітивний, мотиваційний, операційний.

На всіх етапах навчання професійне самовизначення медичної сестри здійснюється за допомогою процесу самоаналізу поведінки, психологічних властивостей особистості, свідомої постановки питань 
професійного розвитку, кар'єрного росту в майбутній професійній діяльності тощо. До пізнання студентів спонукає навчальна мотивація.

У ході нашого дослідження застосовано комплексний підхід, який полягав у поєднанні теоретичного аналізу наукових джерел із емпіричним дослідженням.

Під час проведення емпіричного дослідження використовувалась батарея надійних, валідних, точних психодіагностичних методик для вивчення психологічних чинників впливу на професійне становлення майбутніх медичних сестер.

Мета дослідження - вивчення психолого-педагогічних чинників впливу на професійне становлення майбутніх медичних сестер.

Предметом дослідження виступив навчальний процес як чинник впливу на професійне становлення майбутніх медичних сестер.

Для реалізації даної мети було поставлено такі завдання: емпірично дослідити психологічні чинники впливу на професійне становлення майбутніх медичних сестер; підготувати рекомендації, спрямовані на розвиток професійно важливих психологічних якостей майбутніх медичних сестер; здійснити інтерпретацію отриманих результатів та сформулювати висновки.

Емпіричне дослідження було проведено на базі Ватутінської філії Черкаського медичного коледжу. Вибірку склали 65 студентів першого та третього курсів спеціалізації «Сестринська справа». 3 них 59 дівчат та 6 хлопців 17-21 років.

Емпіричне дослідження включало кілька етапів. На першому етапі було проаналізовано основні теоретичні підходи до вивчення професійного становлення майбутніх медичних сестер. На цьомуж етапі складено програму дослідження, тобто сукупність певних способів і прийомів раціонального використання тих чи інших методів отримання інформації, які включають методи збирання, фіксації та перевірки даних і методи систематизування та аналізу цих даних; визначено об'єкт та предмет дослідження.

Для перевірки гіпотези й розв'язання поставлених завдань у роботі використовувалися такі емпіричні методи дослідження: опитувальник ЕРI (Г. Айзенка) для визначення типу темпераменту, нейротизму, екстраверсії/інтраверсії [10]; тест-опитувальник емпатичних тенденцій (А. Меграбіан, Н. Епштейн) - для встановлення рівня емпатії; методика діагностики комунікативної установки В. В. Бойко [9]; методика для діагностики навчальної мотивації студентів (А. А. Реан, В. А. Якунін, в модифікації Н. Ц. Бадмаєвої) [8].
У результаті дослідження було встановлено, що лише 16,1 \% досліджуваних першокурсників демонструють високий рівень емоційної стійкості.

При цьому більшість першокурсників (61,3%) отримала середні показники, що не виходять за межі норми та вказують на середній рівень вразливості. 22,5\% показали, що їм властива емоційна нестійкість, яка виражається поганою адаптацією, нервуванням, роздратованістю, схильністю до швидкої зміни настроїв, почуттів провини та занепокоєнням, депресивними реакціями, зниженням уваги, нестійкістю в стресових ситуаціях.

При дослідженні рівня нейротизму було встановлено, що 26,5 \% досліджуваних третьокурсників характеризуються високою емоційною стійкістю, емоційна нестійкість встановлена в 20,6 \% респондентів, решта 52,9 \% - мають показники, що перебувають в межах середнього значення.

Порівнюючи отримані результати можна говорити про те, що третьокурсники відзначаються більш високою емоційною стійкістю, ніж першокурсники.

При дослідженні особливостей комунікативних установок особистості було встановлено, що найнижчий рівень комунікативної толерантності досліджувані першокурсники проявляють відносно проявів індивідуальності іншої людини. Найбільше терпимості та більш високий рівень комунікативної толерантності досліджувані готові проявляти відносно фізичного чи психічного дискомфорту, створюваного іншими людьми. Особливості комунікативних установок у групі третьокурсників несуттєво відрізняються від результатів, отриманих в групі першокурсників.

Середній показник загального бала, отриманого при вивченні особливостей комунікативних установок, вказує на середній рівень комунікативної толерантності. Встановлено, що третьокурсники характеризуються вищим рівнем емпатії, ніж першокурсники. Середні значення в першокурсників вказують на середній рівень емпатії, тоді як у групі третьокурсників показник середнього значення в зоні високого рівня.

Виявлено, що 16,1 \% студентів першого курсу медичного коледжу мають низький рівень емпатичних тенденцій, що вказує на недостатній рівень розвитку емоційної чутливості. У решти досліджуваних (83,9\%) встановлено середній рівень розвитку емпатії, при цьому, високого рівня емпатійних здібностей в групі першокурсників встановлено не було.

У групі третьокурсників низький рівень емпатії встановлено лише у 2,9 \% студентів, середній -у 14,7 \% 
і більшість третьокурсників $(82,4 \%)$ демонструє високий рівень емпатії. Більшість першокурсників має середній рівень розвитку емпатії, при цьому, високого рівня емпатійних здібностей в групі першокурсників встановлено не було. В групі третьокурсників більшість демонструє високий рівень емпатії. Тобто, студенти медичного коледжу третього курсу характеризуються високою емоційноючутливістю, тоді якпершокурсники менш чутливі до стану інших.

При вивченні особливостей мотивації було встановлено, що як серед першокурсників, так і в групі третьокурсників домінують навчально-пізнавальні мотиви, на другому місці перебувають професійні мотиви, на останньому місці - мотиви творчої самореалізації.

Було встановлено статистично значущі статеві відмінності за такими змінними, як «індекс емпатійності», мотиви престижу, професійні мотиви та навчально-пізнавальні мотиви, рівень емпатійності, рівень прояву комунікативних, соціальних та мотивів уникнення.

У результаті кореляційного аналізу було встановлено наступне: у досліджуваних студентів, які мають високий рівень особистої нетерпимості при зіткненні 3 некомунікабельними якостями партнерів, знижується рівень навчально-пізнавальної мотивації ( $p$ - 0,031); при зниженні рівня нейротизму, підвищується рівень позитивного оцінювання інших ( $p$ - 0,022).

Висновки. До професійних якостей медичної сестри, що висуваються в професіограмі, відносять

\section{ЛІТЕРАТУРА}

1. Андреева Н. В. Какой должна быть медсестра? / Н. В. Андреева // Сестринское дело. - 2005. - № 5. - С. 18-20.

2. Якість підготовки медичних сестер - нагальна вимога часу / М. В. Банчук, О. П. Волосовець, І. І. Фещенко [та ін.] // Буковинський медичний вісник. - 2007. - С. 7.

3. Васильева Л. А. Особенности формирования профессиональной компетентности будущих медицинских работников среднего звена / Л. А. Васильева // Вестник ОГУ. - 2011. - № 4. - С. 19-22.

4. Галян І. М. Психодіагностика / І. М. Галян. - К. : Академвидав, 2009. - 464 с.

5. Ермолаев О. Ю. Математическая статистика для психологов : учебник / О. Ю. Ермолаев. - 2-е изд., испр. М. : Флинта, 2003. - 336 с.

6. Моргун В. Ф. Основи психологічної діагностики : навч. посіб. для студентів ВНЗ / В. Ф. Моргун, І. Г. Титов. - К. : Видавничий Дім «Слово», 2009. - 464 с.

7. Наследов А. Д. SPSS: Компьютерный анализ данных в психологии и социальных науках / А. Д. Наследов. - СПб. : Питер, 2005. - 416 с. уважність, чуйність, приязність, терплячість та співчуття, володіння комунікативними якостями, які забезпечують ефективну взаємодію з хворими. В нашому дослідженні встановлено, що до психологічних чинників впливу на професійне становлення майбутніх медичних сестер можна віднести «індекс емпатійності», мотиви престижу, професійні мотиви та навчальнопізнавальні мотиви, рівень емпатійності, рівень прояву комунікативних, соціальних та мотивів уникнення.

У навчально-виховному процесі, спрямованому на підготовку майбутніх медичних сестер, для розвитку вказаних у професіограмі психологічних якостей варто спрямовувати педагогічний процес на підвищення комунікативної толерантності, емпатії, сприяти творчій самореалізації студентів.

3 цією метою в медсестринській освіті варто формувати серед студентів пізнавальні мотиви. Під час організації роботи потрібно пам'ятати про основну роль викладача в формуванні мотивації студентів, зокрема, його професіоналізм, об'єктивність та справедливість.

Одна з необхідних умов для створення у студентів інтересу до змісту навчання - це можливість проявляти в навчанні розумову самостійність та ініціативу. Цьому сприяє використання завдань, вирішення яких вимагає від студентів активної пошукової діяльності.

Важливо, щоб у процесі навчання в навчальному закладі прищеплювалися такі якості, як співробітництво, самостійність і прагнення до самореалізації при вирішенні професійно-орієнтованих завдань.

8. Поляченко Ю. В. Медична освіта у світі та в Україні / Ю. В. Поляченко. - К. : Книга плюс, 2005. - 383 с.

9. Практическая психодиагностика. Методики и тесты / [ред.-сост. Д. Я. Райгородский]. - Самара : «Бахрах», 1998. - 672 c.

10. Практикум по общей, экспериментальной и прикладной психологии / В. Д. Балин, В. К. Гайда, В. К. Гербаческий [и др.] ; под общей ред. А. А. Крылова, С. А. Маничева. - СПб. : Питер, 2006. - 560 с.

11. Попіль М. І. Психологічні особливості становлення професійної ідентичності майбутніх медсестер: дис. ... канд. психол. наук : 19.00.07 / М. І. Попіль. Дрогобич, 2009. - 196 с.

12. Радзієвська І. В. Формування професійної компетентності медичних сестер / І. В. Радзієвська // Проблеми освіти. - 2008. - № 57. - С. 69-73.

13. Селлман Д. Как стать медсестрой / Д. Селлман, П. Снеллинг ; пер. с англ. - К. : ВСВ «Медицина», 2012. $176 \mathrm{c}$.

Отримано 28.04.16. 